\title{
CLINICAL PROBLEMS AND LEVELS OF PSYCHOSOMATIC DYSFUNCTION
}

\author{
CLOVIS MARTINS *
}

Levels of dysfunction and psychosomatic symptoms - Mechanistic medical views by the beginning of this century, stimulated by Virchow's cell pathology, did not prevent the uprise of Freud; his revolutionary ideas interpreting human illnesses developed amidst the prevailing organistic approach of European medical thinking at the time. Within the psychiatric field mental illnesses were largely attributed to degenerations, thus increasing the abandonment of mental patients in asylums. Freud and his disciples fought for nearly half a century. to revert the pole of organistic orientation. Even nowadays it is an effort to consider man as an integrated psychophysical unity interacting with the environment. This concept is apparently accepted without further discussion. We talk about it with no hesitation. However, it has not yet reached a definite form capable of allowing holistic approaches and attitudes without the ineluctable dichotomy contained in the very expression "psychosomatic". At every moment of our daily professional chalenges we are betrayed when attempting to put the unitary view of man into practice. This falsehood becomes even more evident when we try to demonstrate our working hypotheses to students. Rational limitations and extremely scant knowledge of psychophysiological mechanisms expose the brittleness of our concepts and the contradictions inherent in the majority of pseudo integrating concepts to interpret psychogenic illnesses.

This difficulty is due to many causes. Human personality resists knowing. itself; teaching anatomy on corpses was a profane act punished with death at the times of Vesalius. Similar obstacles and prejudices are present today in studies of the soul; explorations and comments on certain hiding corners of our mind are held to be infamous obscenities. Physicians do not escape from this. Used to "look outside" when meeting an ill person, the physician shows violent resistances when intending to study, during investigation of psychosomatic disorders, psychological problems very close to or even identified within himself. Ambition, power, money, jealousy, envy and the emotional constellation of the family are some possible roots to psychosocial conflits leading to illnesses. These themes were discussed in seminars with students at the Faculty of Medicine, University of São Paulo, Brazil. Instead of studying patients' case

\footnotetext{
Main Lecture - 3rd Congress of the International College of Psychosomatic Medicine (Rome, sept 19th, 1975). * FICPM; CFAPA; Vice-Presidente (South America) ICPM; Prof. Doc. Liv. Dept. Neuro-Pgychiatry, School of Medicine, såo Paulo Univergity (São Paulo, Brasil).
} 
histories as traditionally done in other areas of the Medicine Course, we focus the discussion on existential experiences of the participating students. Anxiety levels during some of these seminars were so high that continuing the discussion became impossible. We analized this phenomenon in previous papers; it clearly reveals emotional barriers erected when one intends to deepen the knowledge about man and to explain difficulties described by other authors in teaching psychiatry in Medical schools.

Dimensions of personality and psychosomatic diagnosis - Approaching the problem of a body-mind unity as a model in psychosomatic theory, Von Uexkull * says: "As to the goal of body-mind models, there is the generally accepted opinion that psychosomatic medicine has to deal with two components, a body and a mind, since we are approaching the patient with both psychological and physiological methods and since we want to know the significance of the effects of one method upon the other. But can we overlook the following questions? (1) Why must we work with two so different methods? (2) is reality split up in two heterogeneous areas before we have applied our different methods?"

There is in fact no reason why one should approach the problem by creating two different dimensions. On the other hand the medical model of illness offers the only possibility of understanding this problem in a unitary and adequate fashion.

The eventual simplicity of the medical model of thinking does not reduce the proportions or complexity of psychosomatic diagnosis. Difficulties in standardizing psychopathological interpretations and diagnosis terminology employed by psychiatrists of different cultures and latitudes were studied by Zubin ${ }^{\circ}$. He used a personality scheme put forward over a Venn diagram showing the gamut of variables affecting the individual in a certain situation with constant, dynamic and evolving interactions at different levels of integration. Each dimension of this personality scheme needs to be appropriately investigated by specific instruments and methods. Results obtained in the study of one dimension are almost never extensive to the interpretaition of factors from another area.

The ecological sphere (a), for instance, includes remote and embracing sociogenic influences leading to behaviour disorders; it needs to be studied by eridemiologists, whose slow and patient investigations will only produce reliable results through strict statistical methods. The developmental sphere (b) also contains environmental familial factors influencing the development of the child and subsequent adaptation processes of the personality; its observation and recording techniques are entirely different, although results are also assessed by statistical methods. The sphere of learning (c) opens the doors to teachings of reflexologist and behaviourist schools. They have the advantage of combining scientific experiments with careful criticism in their theoretical propositions. The internal sphere (d) involves laboratory investigations of body fluids and the influences of biochemical balance upon psychophysical health; methods used here are far removed from the first two sphere mentioned. Medical investigation of human behaviour is completed by through study of the cerebral sphere (e); instruments and experimentation in neuropsychopathology are technically highly 
sophisticated; its resources are little and badly used. Psychiatrists frequently avoid neuropsychopathology, thus turning away from one of the major possibilities of clinically exploring and interpreting psychosomatic diseases. Present ambiguous medical attitudes, formulations and contradictions are most accentuated in this field. Investigations into psychodynamics and neurophysiological studies on higher cerebral activity develop side by side without ever meeting each other.

This incursion upon possible openings in the study of personality shows clearly the aberrant paradox faced by modern psychosomatic medicine. The rich variety of possible investigation levels does not equip the psychiatrist with an increasing control over causal mechanisms of very complex illnesses; instead, it leads him to doctrinaire radicalism or inoperative perplexity. There is no way of integrating knowledge derived from these various areas and even less of forming really multidisciplinary teams to study these problems in harmonious collaboration.

In my opinion, focusing on the infirm human being through the medical model is the only approach which truly enables us to put forward uniform explanations of increasing complexity for disparate phenomena having in common a resulting pathological behaviour - the illness. The façade of suffering, incapacity and inferiority presented to the world by an ill person is always interpreted as expressing abnormal organic functioning. By moving away from hippocratic medicine the psychiatrist contributes to increase the difficulties in integrating knowledge gained from the various fields of investigation mentioned in the scheme by Zubin.

According to Brendan Maher ${ }^{2}$ the medical model assumes that a person showing disturbed behaviour is ill; the illness, like something within the patient, manifests itself to the observer through a group of more or less clear symptoms. An illness generally has a specific cause; treatment of many illnesses aims at eliminating or controlling the causal agent. To achieve this result the correct identification of aetiology is indispensable, since different illnesses may have symptoms in common. This identification represents the diagnosis, a pre-requisitite to appropriate treatment. This process is further identified by another element, the observation of the course of illness, which finally leads to prognisis as the last medical act in this succession.

The medical model of investigation can be linked to comments by $W$. Knopp ${ }^{1}$ about the psychophysical unity of man. We have to locate in the brain "the most important role in originating and mediating emotional, rational, existential and social aspects of human life". The brain is responsible for maintaining its own balance, the harmony of its functions with the rest of the body and the perfect interaction between body and environment. Traditionally the neurophysiological interpretation of behaviour proposes an "upward, starting from below" dynamics, i.e., from spinal cord and brain stem to sensory motor cortex and frontal lobes. To this dynamics a new dimension is added by Yakolev: "outward, from within". Thus an indissoluble "visceral experience" interacts with an "emotional experience" that can potentially be shared; the conscious "public experience" can alway be shared and is part of social life. 
Responses to environmental demands on man are elaborated and integrated within the depth of the cerebral functional complex. For this reason the solutions for obscure points still in need of clarification will be discovered with an increasingly deeper and more complete knowledge of the central nervous system. Only the physician can, as a medical man, have broad and integrated views of the human heing in the world, investigating cerebral functions and understanding resources mobilized by cerebral subsystems which harmoniously overcome conflict situations.

In recent years the applicability of the medical model to psychopathology has been questioned. On one extreme are those who dispense with classical diagnosis and nosology, considered unnecessary to institute treatment. On the other extreme are those who simply renounce the medical spirit when faced with pathological behaviour, looking upon the psychiatrist as an undesirable and harmful intruder in the analysis and control of human behaviour.

Multiple compromise levels and numerous expressive façades in psychosomatic pathology can be identified by adequate and simple use of purely medical reasoning and instruments. This will be illustrated by three case histories from my own professional experience $3,5 . \quad 6$. These patients were studied in the Psychiatric Clinic at the general hospital attached to the Medical Faculty of the University of São Paulo (Head: Prof. Fernando de Oliveira Bastos), where I teach Psychosomatic Medicine.

\section{OBSERVATIONS}

CASE 1 - A 27 years old man, ill for 10 years, is treated for gastric ulcer by gastroenterologists at this general hospital. Emergency operation for what seems an acute abdomen reveals no abdominal or gastric mucosal abnormality. Referred to psychiatrists because of suspected neurosis he is discovered to suffer from visceral (abdominal) epilepsy, with abdominal pain episodes similar to dyspeptic crises; cerebral dysrhythmia in the left temporal lobe is confirmed as cause of his symptoms. This downcast, suffering, thin and defeated human being reports during his first psychiatric consulation that he had lived at the expenses of relatives for the last ten years, unable to work and devoid of resources. He feared the next abdominal crisis episode despite its paroxysmal nature and low frequency. Out of fear he reduced his eating to a minimum, apart from being on restricted medical diet. To the strictly followed medical treatment he added advice and prescriptions from healers and neighbours.

CASE 2 - A 54 years old woman, ill for 25 years, presents intermittent acute abdominal episodes with nausea, vomiting and colicky pain. Although vague, this syndrome is considered to be renal in origin. Complaints of profound suffering and dramatic appeals to alleviate her pain lead to 7 extensive abdominal operations (indicated without much conviction) in different hospitals. Some surgeons remark on her abnormal mental state during these episodes; one also diagnoses "hysteria". The patient rapidly recovers from an acute episode receiving antidepressants in our Clinic; her diagnosis was depressive episode with syndrome of Cotard in a manic depressive psychosis (fig. 1). 
CASE 3 - An adolescent girl of 16 years of age presents for a whole year extensive, bizarre and complicated skin lesions of exposed areas mainly on her left arm. Diagnosis of dermatitis artefacta is made and after one year of treatment she is referred to psychiatrists. This girl was adopted at 7 years of age by a very rich couple to be a companion for their daughter, one year younger. When seen by us the patient shows signs of what I call "affective cross breeding" - she benefits from some advantages as member of the family, but with certain activities she is often put at the level of other servants. These hybrid roles become more accentuated during adolescence; the social distance between herself and the couple's daughter increases subtly. The rich daughter matures, becomes more feminine and looks for male company. Until then both girls had been linked by affective ties in socially compatible and tolerated areas; now the patient feels that she has no place in the competition for male company at that social level. Her role seems to have come to an end. She decides to create and maintain deforming skin lesions on arms and hands to regain her stumbling position and to insure her important presence in the family. For a long time she becomes a point around which the worries of the family gravitable. She causes concern mainly for her adoptive mother who she wishes to "punish, making her suffer as much as I am suffering".

\section{DISCUSSION}

These 3 patients presented from the very beginning inequivocal signs of psychological dysfunction. Physicians only took these into account after stubbornly investigating the somatic aspects of bizarre and atypical clinical pictures, within themselves quite revealing of a "psycho-cerebral" origin.

The first patient presented a cerebral function disorganized at an elemental level, i.e., the neuronal level, as shown by electroencephalogram in his left temporal lobe. Abnormal discharges led to "visceral experiences", progressively involving other integrating systems of the personality to "explain" and surmount his suffering by intelectual and socio cultural resources in tune with his environment. Seeking relief the patient devoted himself to diets and eating rituals which enhanced his suffering and transformed him into a downcast and tormented invalid. A rapid readjustment of the personality may occur once the biolectric dysfunction is corrected (Fig. 1).

More complex structures became disorganized in the second patient. The balance of chemical transmitters in synapses of the limbic system was altered. Deep changes in affective tonus reduced her sensibility threshold to visceral stimuli and distorted her vision of the world. Sombre, pessimistic mood linked with hypochondriasis led the patient to concentrate her psychic life upon visceral problems felt and lived as threatening and catastrophic. Appeals for surgery provided self retaliation and risk of death needed by the patient to satisfy her profound guilt feelings. Once the affective tonus was modified by antidepressants a visceral silence ensued, eliminating all gloomy and self destructive living experiences (Fig. 1). 


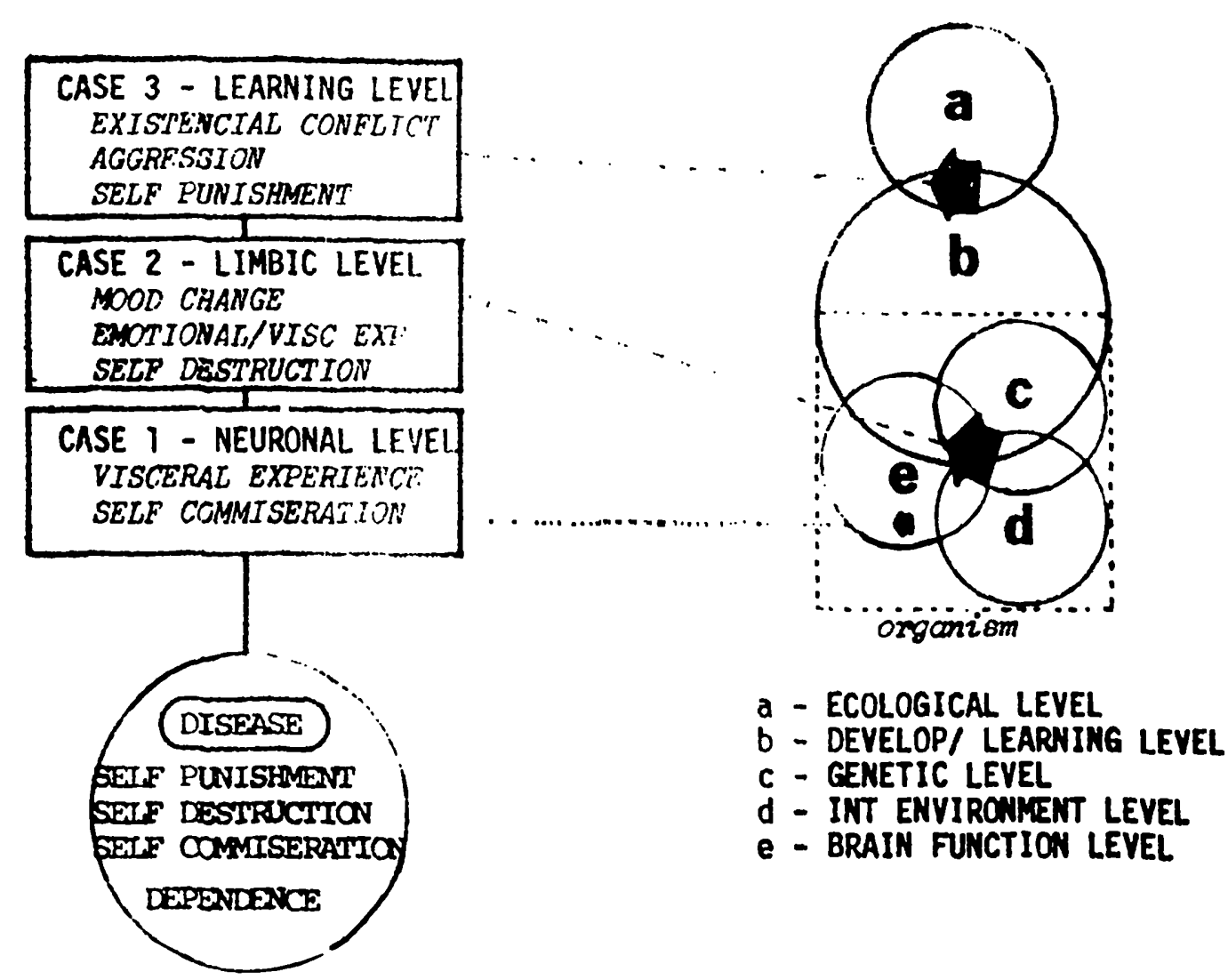

F'ig. 1 - Schematic representation of lovels of psychosomatic dysfunction in the cases studied.

Changes were imposed "from without" in the third patient by psycho-social distortions in her relations with the world during a critical period in the development of her personality. Within learning and developmental areas she introjected blurring of roles, rough discriminations and unjust or even deceitful propositions originating from an artificial, prejudiced and defectively organized social group. Her existential and emotional experiences occurred in a world she was led to believe she would participate. However, she slowly noticed that this was not her world. The first half of her life was spent in misery and abandonment with all sorts of material and emotional deprivations (Fig. 1). Wealth and confort seemed to shine in the second half of her life. But she slowly realized they did not belong to her. She would be excluded from this world by being normal and healthy; she would be included in it as long as her mutilated, scarred, ill figure remained the object of pity and complacency by her protectors. She paid the price demanded. During the 3 years we followed her up, this patient continued to rely on indelible scars stamping her body. She carried the calm and safe conviction that bearing these scars she could not be returned to the resourceless environment they had removed her from because of lack of survival conditions.

These examples have in common: $a$ ) an incontestable and dramatic somatic expression of psychological distortions; $b$ ) to these were added unequivocal psychological alterations, ignored or minimized on initial examinations; $c$ ) all cases produced the stereotype of an "ill person", patients were viewed and treated in this ligth; despite its difficulties only the medical model is compatible with 
varied stages and directions demanded by complexities of each patient; $d$ ) the unadorned and simple views of the medical model can be applied to complete and exact studies and treatment of other commoner and less bizarre psychosomatic conditions. All presentations from peptic ulcers to more sophisticated and diffuse expressions of metabolic pictures allow for unity and fruitbearing views implicit in the convenient use of the medical model of thinking.

A personality in conflict acquires new social values through an illness. Certain degrees of emotional balance are obtained by the personality in its interpersonal relations and insertion into the world through the symbolism of an illness. This happens at the expense of severe restrictions, certain impulses or intense suffering. The "illness model" chosen by the personality as the solution to conflicts must be matched with the corresponding medical model able to explain and resolve it.

\section{SUMMARY}

As an introduction, some doctrinary and technical problems dealing with the complexity of the human mind and the possible approaches to investigate and treat the personality are discussed and, among them, the "medical model" is emphasized. A brief description of some cases in the author's experience are presented; they, at first, had been very difficult to diagnose. However, after some time, they were found to be of indisputable neuro-psychogenetic pathogenesis. The psychosomatic aspects of each case are analyzed, with emphasis on the different levels of pathogenic action and the means of elaboration to defend and readapt the affected personality, resulting in its final clinical expression. There are four possible levels where the primary dysfunction may act; (a) physiopathologic neuronal level; (b) cerebral subsystemic level; (c) psychodynamic level; (d) psychosocial level. The primary dysfunction, acting as a new stimulus on each of these levels, may determine in the personality pathologic responses that may assume very complex clinical situations. Many of these responses are quite different from the precipitating primary dysfunction, although there are still many evident links among them.

\section{RESUMO}

Preliminarmente são feitas algumas colocações doutrinárias e técnicas, pertinentes à análise da complexidade do psiquismo humano e das linhas de abordagem possiveis para investigar, diagnosticar e tratar a personalidade; dentre elas, é dada especial enfase ao estudo do "modelo médico". Segue-se breve descrição de alguns casos da experiência do autor, observados e tratados na Clínica Psiquiátrica do Hospital das Clínicas da Faculdade de Medicina da Universidade de São Paulo (Serviço do Prof. F. O. Bastos), os quais inicialmente apresentaram-se com inequívocas caracteristicas de doenças somáticas, porém de diagnóstico muito difícil; contudo, depois de algum tempo, mostraram-se de inquestionável patogenia neuro-psicogênica. São analisados os as- 
pectos psicossomáticos de cada um, sublinhando-se os diferentes niveis da ação patogênica no plano neuropsiquico e os meios de elaboração usados na defesa e readaptação da personalidade afetada, disto resultando sua expressão clínica final. Sugerem-se quatro niveis possiveis onde a disfunção primária possa assestar-se: a) nível fisiopatológico neuronal; b) nivel subsistêmico cerebral; c) nível psico-dinâmico; d) nível psicossocial. A disfunção primária, atuando também como novo estimulo em cada um destes niveis, pode determinar na personalidade, respostas patológicas suscetíveis de assumir feições clínicas complexas. Muitas destas respostas costumam ser muito diferentes e, na aparência, remotas da disfunção primária precipitante, não obstante estudo cuidadoso mostrar evidentes laços entre aquelas e esta.

\section{REFERENCES}

1. KNOPP, w. - Man's tripartite brain and psychosomatic Medicine. In Recent Research in Psychosomatics - Ed. A. Pierloot. S. Karger, London, 1970 (pp. 103-136).

2. MAHER, B. - Introduction to Research in Psychopathology. McGraw Hill, New York (N.Y.), 1970.

3. MARTINS, C. - Epilepsia visceral. Rev. Hosp. Clín. Fac. Med. USP, 14: 348, 1959.

4. MARTINS, C - La enseñanza de psicologia médica y grupos operacionais (Grupos T). In Psychiatry. Excerpta Mŕdica International Congress Series No 150 (pp. 3145-3147), Amsterdam, 1968.

5. MARTINS, C. \& SAMPAIO, S. A. P. - Dermatite facticia. Aspectos psicológicos e dermatológicos de um caso. Rev. Paul. Med. 56: 300, 1960.

6. MARTINS, C. \& VILLAR, Z. - Patominia e policirurgia em sindrome depressiva. Rev. Hosp. Clin. Fac. Med. USP, 14: 354, 1959.

7. WEINER, H. - The mind-body-unity in the light of recent physiological evidence. In Recent Research in Psychosomatics - Ed. A. Pierloot. S. Karger, London, 1970 (pp. 117-122).

8. UEXKULL, Th. VON - The problem of psychosomatic theory and the mind-body-unity model. In Recent Research in Psychosomatics - Ed. A. Pierloot. S. Karger, London, 1970 (pp. 103-116).

9. ZUBIN, J. - Cross-National study of diagnosis of mental disorders: «methodology and planning». Am. J' Psychiat. 125: supl. 1/12-20, 1969.

Rua Itapeva 490, conj. 103 - 013.32 São Paulo SP - Brasil 